\title{
Cattle mortality as a sentinel for the effects of ambient air pollution on human health
}

\author{
Bianca Cox ${ }^{1 *}$, Antonio Gasparrini ${ }^{2}$, Boudewijn Catry ${ }^{3}$, Frans Fierens ${ }^{4}$, Jaco Vangronsveld ${ }^{5}$, Tim Nawrot ${ }^{5}$ \\ From Methods in Epidemiology Symposium \\ Leuven, Belgium. 17 September 2015
}

\section{Background}

Air pollution is a trigger for human mortality. Although studies of spontaneous animal disease can provide additional insights, the short-term effects of air pollution on mortality have never been studied in animal populations. Animal sentinels are less subject to concurrent exposures, bias due to confounding, and exposure misclassification than human populations. Therefore we investigated the association between ambient air pollution and the risk of mortality in dairy cows.

\section{Methods}

We collected ozone $\left(\mathrm{O}_{3}\right)$, particulate matter $\left(\mathrm{PM}_{10}\right)$, and nitrogen dioxide $\left(\mathrm{NO}_{2}\right)$ concentrations at municipality level for 87,108 dairy cow deaths in Belgium from 2006 to 2009. We combined a case-crossover design with distributed lag nonlinear models in the warm and cold period of the year.

\section{Results}

We found acute and delayed effects of air pollution on dairy cattle mortality during the warm season. The increase in mortality for a $10 \mu \mathrm{g} / \mathrm{m}^{3}$ increase in 2-day (lag 0-1) $\mathrm{O}_{3}$ was $1.3 \%$ (95\% CI: 0.3, 2.2), and the corresponding estimates for a $10 \mu \mathrm{g} / \mathrm{m}^{3}$ increase in same-day (lag 0 ) $\mathrm{PM}_{10}$ and $\mathrm{NO}_{2}$ were $1.2 \%$ (95\% CI: $\left.-0.3,2.8\right)$ and $9.4 \%$ (95\% CI: 6.4, 12.4), respectively. Compared to the acute effects, the cumulative 26-day (lag 0-25) estimates were considerably larger for $\mathrm{O}_{3}(3.6 \% ; 95 \% \mathrm{CI}: 0.4,6.9)$ and $\mathrm{PM}_{10}$ (5.1\%; 95\% CI: 0.8, 9.5), but not for $\mathrm{NO}_{2}(2.9 \%$; 95\% CI: $-4.1,10.3)$. We did not find consistent evidence for air pollution effects during the cold period.

\section{Conclusions}

Our study in cattle adds to the epidemiologic findings in human populations and further improves its causality.

\footnotetext{
${ }^{1}$ UHasselt, Diepenbeek, Belgium

C Biomed Central
}

Full list of author information is available at the end of the article
Furthermore, our results indicate that air pollution effects go beyond short-term mortality displacement. Compared with human studies, we observed higher mortality risk associated with air pollution among cattle, suggesting that dairy cows may be sensitive indicators of air pollution and provide an early warning system for public health intervention.

\begin{abstract}
Authors' details
${ }^{1}$ UHasselt, Diepenbeek, Belgium. ${ }^{2}$ London School of Hygiene \& Tropical Medicine (LSHTM), London, United Kingdom. ${ }^{3}$ Scientific Institute of Public Health (WIV-ISP), Brussels, Belgium. ${ }^{4}$ Belgian Interregional Environment Agency (IRCEL-CELINE), Brussels, Belgium. ${ }^{5}$ Hasselt University, Diepenbeek, Belgium.
\end{abstract}

Published: 17 September 2015

doi:10.1186/2049-3258-73-S1-P22

Cite this article as: Cox et al:: Cattle mortality as a sentinel for the effects of ambient air pollution on human health. Archives of Public Health 2015 73(Suppl 1):P22.

Submit your next manuscript to BioMed Central and take full advantage of:

- Convenient online submission

- Thorough peer review

- No space constraints or color figure charges

- Immediate publication on acceptance

- Inclusion in PubMed, CAS, Scopus and Google Scholar

- Research which is freely available for redistribution (c) 2015 Cox et al. This is an Open Access article distributed under the terms of the Creative Commons Attribution License (http:// c 2015 Cox et al. This is an Open Access article distributed under the terms of the Creative Commons Attribution License (http://
creativecommons.org/licenses/by/4.0), which permits unrestricted use, distribution, and reproduction in any medium, provided the original work is properly cited. The Creative Commons Public Domain Dedication waiver (http://creativecommons.org/publicdomain/ zero/1.0/) applies to the data made available in this article, unless otherwise stated. 